\title{
AN ISLAMIC PERSPECTIVE ON PREVENTING SEXUAL ABUSE AGAINST CHILDREN
}

\author{
Nasimah Hussin * \\ Hanifah Haydar Ali Tajuddin **
}

\begin{abstract}
Sexual abuse against children in Malaysia has been consistently on the rise. The Ministry of Women, Family and Community Development, Malaysia has stated that a total of 1,721 cases of sexual crimes against children were recorded in the first half of 2020. Most offenders in such cases were family members, guardians and those close to the children. This is an alarming number. Islam treats sexual abuse against children as a serious offence that must be strictly curbed. In Islam, any sexual activity out of wedlock is condemned and considered as a punishable act. It is even worse when the act is committed against the will of victim or it is committed against those who are physically and mentally weak as well as those whose consent is not yet valid such as children. This article discusses measures to prevent sexual abuse against children which are derived from the Shari'ah principles. It adopts a doctrinal study of existing primary and secondary materials relating to theories of victimization and methods to prevent criminal victimization against children from the Islamic perspectives. Hence, Shari'ah texts and juristic views on the relevant issues are essential to be analysed. The finding of this article confirms that Islam has a unique approach to deal with this issue and to even prevent the crime before it is committed. Islam suggests proactive steps that could be observed by individuals, guardians, the community as well as authorities concerned to ensure that the children are protected and do not become gullible victims.
\end{abstract}

Keywords: sexual abuse against children, Shari'ah principles on prevention of sexual abuse, criminal victimization, prevention of sexual abuse.

* Associate Professor, Ahmad Ibrahim Kulliyyah of Laws, International Islamic University Malaysia. Email: nasimah@iium.edu.my.

** Senior Assistant Director, Policy and Research Unit, Syariah Judiciary Department Malaysia. Email: hhat_82@yahoo.com. 


\title{
PENCEGAHAN PENDERAAN SEKSUAL TERHADAP KANAK-KANAK MENURUT PERSPEKTIF ISLAM
}

\begin{abstract}
ABSTRAK
Kes penderaan seksual terhadap kanak-kanak di Malaysia semakin meningkat. Kementerian Pembangunan Wanita, Keluarga dan Masyarakat, Malaysia menyatakan bahawa sejumlah 1721 kes jenayah seksual terhadap kanak-kanak direkodkan dalam tempoh setengah tahun pertama 2020. Kebanyakan pesalah yang terlibat dalam kes tersebut adalah dalam kalangan ahli keluarga, penjaga dan golongan yang rapat dengan kanak-kanak terbabit, Perkara ini amat membimbangkan. Islam menganggap penderaan seksual terhadap kanak-kanak sebagai satu kesalahan serius yang mesti ditangani dengan tegas. Dalam Islam, apaapa sahaja perbuatan seksual luar nikah adalah dilarang dan dianggap sebagai kesalahan yang boleh dihukum. Malah, perbuatan ini lebih serius jika ia dilakukan tanpa kerelaan mangsa ataupun dilakukan terhadap mereka yang lemah dari segi fizikal dan mental yang mana persetujuannya tidak sah dari segi undang-undang seperti kanak-kanak. Islam mengambil satu pendekatan yang unik dalam menangani jenayah ini agar dapat dielakkan sebelum ia berlaku. Maka artikel ini ditulis untuk membincangkan langkah-langkah pencegahan penderaan seksual terhadap kanak-kanak berdasarkan prinsip-prinsip Shari'ah. Kajian ini adalah kajian penyelidikan secara doktrinal ke atas literatur primer dan sekunder sedia ada berkenaan teori pemangsaan kanak-kanak dan pencegahannya menurut perspektif Islam berdasar kepada al-Qur'an, Hadith dan pandangan fuqaha'. Dapatan penulisan ini mendapati bahawa Islam mengambil satu pendekatan yang unik dalam menangani jenayah ini agar dapat dielakkan sebelum ianya berlaku. Artikel ini menyarankan langkah-langkah proaktif sebagaimana yang dinyatakan dalam Islam yang perlu diambil oleh individu, penjaga, masyarakat serta pihak berkuasa untuk memastikan agar kanak-kanak dilindungi dan seterusnya terselamat daripada menjadi mangsa.
\end{abstract}

Kata kunci: penderaan seksual terhadap kanak-kanak, pencegahan jenayah seksual menurut prinsip-prinsip Shari'ah, pemangsaan kanak-kanak, pencegahan penderaan seksual terhadap kanak-kanak. 


\section{INTRODUCTION}

The number of sexual abuse cases against children in Malaysia is still high despite efforts that have been made by the Ministry of Women, Family and Community Development, to prevent the commission of the offence. ${ }^{1}$ Such efforts, include the imposition of a maximum penalty of RM20,000, ten years jail or both ${ }^{2}$ on the offenders as punitive and deterrent measures. In 2017, the punishment has been further increased to a maximum of thirty years imprisonment, a minimum whipping of six strokes, or a maximum RM20,000 fines under the Sexual Offences against Children Act, 2017. ${ }^{3}$ The Royal Malaysian Police data for the year 2012 showed 2,584 reported child related cases; whereby, 2,299 cases were child rape cases. Table 1 states that for the years 2013-2017, reported child sexual abuse cases were 1,093 cases for 2013, 984 cases for 2014, 978 for 2015, 1038 for 2016 and 1397 for $2017 .^{4}$

Table 1: Child Sexual Abuse from 2013-2017.

\begin{tabular}{|l|l|l|l|l|l|}
\hline Year & $\mathbf{2 0 1 3}$ & $\mathbf{2 0 1 4}$ & $\mathbf{2 0 1 5}$ & $\mathbf{2 0 1 6}$ & $\mathbf{2 0 1 7}$ \\
\hline No. of cases & 1093 & 984 & 978 & 1038 & 1397 \\
\hline
\end{tabular}

Studies have shown that only 10 per cent of perpetrators in child sexual abuse cases were strangers. Most sexual abuse offenders are known to their victims, about 30 per cent are relatives of the child, including fathers, mothers, brothers, uncles or cousins; and 60 per cent are acquaintances such as family friends, nannies or babysitters, or

1 https://malaysiagazette.com/2020/08/18/jenayah-seksual-kanak-kanakmembimbangkan/ (accessed on 13 October 2020).

2 Child Act 2001, s.31 (1). The Child Act 2001 was amended in2016(A1511 Act) where it observed the Convention of the Rights of Children (CRC) signed by Malaysia back in 1995. The amendment introduced the establishment of Child Sex Offenders Registry and family-based care for abandoned children. It also includes specified chapter for community service order.

3 Sexual Offences against Children Act 2017, s.5.

4 Source: Welfare Department Malaysia, as cited by Norsaleha Mohd. Salleh in International Journal for Studies on Children, Women, Elderly and Disabled.5 (October) 2018. 
neighbours. The statistics on the crime of incest can be seen in Table 2 below. Between 2013 and 2017, a total of 1,353 incest cases were reported. ${ }^{5}$

Table 2: Incest Cases Reported in Malaysia (2013-2017).

\begin{tabular}{|l|l|l|l|l|l|}
\hline Year & $\mathbf{2 0 1 3}$ & $\mathbf{2 0 1 4}$ & $\mathbf{2 0 1 5}$ & $\mathbf{2 0 1 6}$ & $\mathbf{2 0 1 7}$ \\
\hline No. of cases & 249 & 304 & 251 & 253 & 286 \\
\hline
\end{tabular}

Table 3 states that most of the incest victims were below 18 years old. The largest number of reports were from the 13-15-year-old category. Gender of incest victims involved female victims only. ${ }^{6}$

Table 3: Age Distribution of Incest Victims (2013-2017)

\begin{tabular}{|l|c|c|c|c|c|}
\hline \multicolumn{1}{|c|}{ Age } & $\mathbf{2 0 1 3}$ & $\mathbf{2 0 1 4}$ & $\mathbf{2 0 1 5}$ & $\mathbf{2 0 1 6}$ & $\mathbf{2 0 1 7}$ \\
\hline Below 12 years old & 65 & 70 & 60 & 59 & 69 \\
\hline 13-15 years old & 96 & 125 & 103 & 88 & 115 \\
\hline 16-18 years old & 49 & 51 & 47 & 46 & 59 \\
\hline Above 18 years old & 39 & 58 & 41 & 60 & 43 \\
\hline Total & $\mathbf{2 4 9}$ & $\mathbf{3 0 4}$ & $\mathbf{2 5 1}$ & $\mathbf{2 5 3}$ & $\mathbf{2 8 6}$ \\
\hline
\end{tabular}

Table 4: Relationship between Victim and Suspect (2014-2017).

\begin{tabular}{|l|c|c|c|c|}
\hline Relationship with Suspect & $\mathbf{2 0 1 4}$ & $\mathbf{2 0 1 5}$ & $\mathbf{2 0 1 6}$ & $\mathbf{2 0 1 7}$ \\
\hline Father/Step-/Adopted Father & 163 & 134 & 133 & 29 \\
\hline Uncle & 54 & 45 & 36 & 16 \\
\hline Brother/ Step-/Foster brother & 56 & 42 & 50 & 12 \\
\hline
\end{tabular}

5 Source: Royal Malaysian Police. https://wao.org.my/incest-statistics/ (accessed on 14 October 2020).

6 Source: Royal Malaysian Police. https://wao.org.my/incest-statistics/ (accessed on 14 October 2020). 


\begin{tabular}{|l|c|c|c|c|}
\hline Brothers In-law & 15 & 29 & 18 & 4 \\
\hline $\begin{array}{l}\text { Grandfather/Grand- } \\
\text { uncle/Step-Grandfather }\end{array}$ & 13 & 8 & 22 & 3 \\
\hline Cousins/Nephew/Relatives & 13 & 9 & 14 & 3 \\
\hline Father/Son In-law & 3 & 1 & 1 & 0 \\
\hline Child/ Stepson/grandson & 1 & 1 & 1 & 2 \\
\hline Total & $\mathbf{3 1 8}$ & $\mathbf{2 6 9}$ & $\mathbf{2 7 5}$ & $\mathbf{6 9}$ \\
\hline
\end{tabular}

It can be seen in Table 4 that between 2014 and 2017, fathers (biological, step or adopted) accounted for almost half of the alleged suspects. ${ }^{7}$

\section{DEFINITION OF CHILD SEXUAL ABUSE}

Before this issue is discussed further, it is necessary to understand the meaning of the term "child" within the context of law. The (UN) Convention on the Rights of the Child 1989 defines children as:

All human beings under the age of 18 , unless the relevant national laws recognize an earlier age of majority. (Article 1)

In Malaysia, there are a number of statutes;which have provisions on this issue. They however, vary slightly from one statute to the other as each of the statutes is meant for specific needs and purposes. The most relevant provision defining the word "child" is section 2 of the Malaysian Child Act 2001 (Act 611) ${ }^{8}$, which states that a "child" is:

(a) a person under the age of eighteen years; and

7 Source: Royal Malaysian Police.

https://www.pressreader.com/malaysia/new-straitstimes/20170630/281479276430562. (Accessed on 18 October 2020).

8 Provisions in the Child Act 2001 are combination of three Acts which have been repealed, i.e., the Women and Girls Protection Act 1973 (Act 106), the Child Protection Act 1991 (Act 468) and the Juvenile Courts Act 1947 (Act 90). 
(b) in relation to criminal proceedings, means a person who has attained the age of criminal responsibility as prescribed in section 82 of the Penal Code [Act 574].

As regards to the meaning of child abuse, WHO defines it as all forms of physical and/or emotional ill-treatment, sexual abuse, neglect or negligent treatment, or commercial or other exploitation resulting in actual or potential harm to the child's health, survival, development, or dignity. ${ }^{9}$ According to this definition, child abuse can be classified into five types inter alia: physical abuse, sexual abuse, neglect and negligent treatment, emotional abuse and commercial exploitation.

\section{Types of child abuse}

The five types of child abuse ${ }^{10}$ can be further elaborated as follows:

(i) Physical abuse: it is that which results in actual or potential physical harm from an interaction or lack of interaction, which is reasonably within the control of a parent or person in a position of responsibility, power or trust. For instance, slapping, hitting with the hand or an object, punching, kicking, pushing, beating, and pinching.

(ii) Sexual abuse; it is the involvement of a child in sexual activity that he or she does not fully comprehend, is unable to give informed consent to, for which the child is not developmentally prepared and cannot give consent, or that violate the law or social taboos of society. This includes the inducement or coercion of a child to engage in any sexual activity, the use of a child in sexual practices e.g., prostitution, and the exploitative use of children in pornographic performances and materials. The types of child sexual abuse are mentioned in the latest Malaysian Sexual Offences Against Children Act 2017 to include child pornography, child grooming, and sexual assault.

(iii) Neglect and negligent treatment; it is the deliberate inattention or omission on the part of the caregiver to provide for the

9 World Health Organisation (WHO)'s World Report on Violence and Health (2002) in Child Protection System in Malaysia, Ministry of Woman, Family and Community Development and UNICEF Malaysia (2013) 9.

10 Ibid. 
development of the child in all spheres: health, education, emotional development, nutrition, shelter, and safe living conditions, in the context of resources reasonably available to the family, or has a high probability of causing harm to the child's health or physical, mental, spiritual, moral or social development. This includes the failure to properly supervise and protect children from harm as much as is feasible.

(iv) Emotional abuse; this includes the failure to provide a developmentally appropriate, supportive environment, so that the child can develop a stable and full range of emotional and social competencies commensurate with his or her personal potential and in the context of society in which the child dwells. Acts include restriction of movement, patterns of belittling, threatening, scaring, discriminating, ridiculing or other non-physical forms of hostile treatment or rejection.

(v) Commercial exploitation; it refers to use of child in work or other activities for the benefit of others. This includes harmful child labour, sale of children, child prostitution, and the exploitation of children through pornography.

This article focuses on child sexual abuse, as it is a serious issue that is concerned by Malaysians ${ }^{11}$. Child sexual abuse cases have been on the rise recently as evidenced by news portals. ${ }^{12}$ It dominates discussion at various levels and raises concern among the public, law enforcement officers and so on. Since independence, the government of Malaysia has managed to put the country in a well-established position economically, socially and politically that any Malaysians can be proud of. However, the rise in child sexual abuse cases is an issue that must not be neglected, as this will affect future generations that are supposed to lead the country.

The objective of this article is to provide suggestions as to how this issue could be curbed by adopting preventive measures based on Shari'ah principles. This is done by analysing relevant Shari'ah literature mainly the Qur'an and the hadith of the Prophet, classical

11 https://malaysiagazette.com/2020/08/18/jenayah-seksual-kanak-kanakmembimbangkan/ (accessed on 13 October 2020).

12 https://www.thestar.com.my/news/nation/2020/08/18/1721-cases-ofsexual-crimes-against-children-recorded-in-first-half-of-2020 (accessed on 14 October 2020). 
manual fiqh including those of four sunni scholars and their eminent disciples. Hence, this article will concentrate on aspects of preventive measures that can be observed by individuals, community and authorities to prevent sexual abuse against children from the Islamic.

\section{FACTORS THAT CONTRIBUTE TO CHILD SEXUAL ABUSE}

Sexual abuse can happen to any child regardless of race, socioeconomic status, religion and national boundaries. In theory, anybody can become a victim of a crime; nevertheless, a particular person or members of certain groups are more vulnerable than others. For instance, the minor, the old or the elderly, the female, the tourist, the poor, the urban dweller are all more vulnerable to become crime victims than others. According to a study, child abuse cases are more often detected among the lower socio-economic level. In terms of gender, it is found out that young girls are more likely to be abused either physically or sexually. Von Hentig, the first victimologist to study the risk factors believes that certain personal attributes have some effects in deciding the vulnerability of some individuals to crime. ${ }^{13}$ Among the factors that make a child vulnerable to become a victim are listed below.

\section{a. Physically and mentally weak}

Von Hentig maintains that those who are inexperienced and mentally weak such as new immigrants, less educated and illiterates could be appealing targets for exploitation by offenders through deception and fraud ${ }^{14}$. Those who are physically weak such as the elderly, the minor and the female are believed to be effortless targets for physical attacks and robberies ${ }^{15}$. Chokalingam states that in determining the targets, a smart criminal would opt for the weaker one if he has to choose

13 Von Hentig, H. Remarks on the interaction of perpetrator and victim. Journal of criminal law, criminology, and police science.31 (MarchApril), 1941. 303.

14 Ibid.

15 Chockalingam, K. UN Declaration of basic principles of justices for victims of crime and abuse of power, a Handout for the $7^{\text {th }}$ Asian Postgraduate Course on Victimology and Victim Assistance. Mito Japan, 2007. 
between the two victims, otherwise the target would be anyone of equally placed victims. ${ }^{16}$

Generally, it is an undeniable fact that mental capacity of a child and his or her physical condition can be considered infirm and fragile. Thus, a child is vulnerable to become an easy target to be abused.

\section{b. Opportunity}

Chockalingam states that access to a potential victim is an important factor in determining a particular person to become a victim rather than another person. It gives sufficient opportunity to the criminal to commit the crime against the victim. Usually, criminals are residing in the same areas with the victims that make them clearly identifiable as targets. He also explains that the relationship of the victim to the offender could be any of the following, i.e., member of the same family, lover, friend, acquaintance, stranger, rival or enemy. One of the closest relationships between the victim and the criminal is being a member of the same family. For example, the crime of incest can be committed within the family. When the family could not afford to provide a decent home for its members such as a house without enough bedrooms for son and daughter, this might expose to sexual abuse in the family. ${ }^{17}$

A child who is left at a playground unguarded can be an easy target of kidnappers. Similarly, a young student who walks alone through a quiet alley might open opportunity for the criminal to abuse him or her. In the same vein, progress in technology and development in IT (information and communication technologies) has exposed our youngsters to the harmful effect of social media as it opens opportunity for the predators and paedophiles to hook their preys including these unsuspicious ignorant children who might trust strangers easily. ${ }^{18}$

\footnotetext{
16 Ibid.

17 Chockalingam, Ibid.

18 https://www.sinarharian.com.my/article/75989/LAPORAN KHAS/ Penjenayah-seksual-guna-aplikasi-sosial-jerat-kanak-kanak (accessed on 8 November 2020).
} 


\section{c. Lifestyle}

Many criminologists assume that those whose lifestyle increases criminal exposure are more likely to become victims of crime. Behaviours such as going out late at night, associating with younger persons and residing in urban areas increase risk of becoming a victim. Therefore, the chance of becoming a victim can be reduced by staying home at night, living in a suburban area, avoiding public areas, and getting married. ${ }^{19}$

Those who choose high-risk lifestyles that include taking drugs, drinking, and participating in criminal activities, their risk level of becoming victims is much higher. Youngsters in particular have a very high risk of victimization. Likewise, teenagers who tend to spend nights partying habitually are also more prone to be at risk than those who avoid such unstable lifestyles. As these children are obsessed with such lifestyles, predators may target them as their prey for sexual gratification or other criminal activities without them realizing it. ${ }^{20}$

\section{d. Routine activities}

This theory concludes that the "volume and distribution of predatory crime" are closely linked to three variable interactions that present the typical 'routine activities' executed in an American traditional lifestyle. These variables include:

(1) available and suitable targets such as unlocked homes in which a child is staying alone,

(2) no proper guardians such as police, homeowners, neighbours, and relatives, and

(3) the presence of potential offenders such as addicts, paedophiles and those who are unemployed.

The presence of such components increases the probability of the occurrence of child sexual abuse crime. ${ }^{21}$

19 Siegel, L. Criminology. 9th ed. Belmont, (CA: Thomson Wadsworth, 2006). 80

20 Siegel, L. Criminology. Ibid.

21 Ibid. 


\section{e. Other factors}

It is an acknowledged fact that there is no religion in the world which legalises illicit sexual intercourse out of wedlock. ${ }^{22}$ All religious teachings enjoin their believers to observe good morals and virtues. Therefore, it can be assumed that sexual abuse against children would not have been committed if the person has a strong hold of his religious belief.

Socio-economic factors can also contribute to child sexual abuse cases, which underlies overcrowding and inadequate accommodation. Poverty urges affected families to use their children as sex workers in order to meet their basic needs. Needy children can also fall victim to adults who pretend to help them. Some predators target children who are neglected by their parents. Social change in the society has also affected the family structures and has led to many single-parent families, and step-parent families. The latter often leaves the girl child vulnerable to stepfathers. Social change was also found to be associated with the high rate of divorce and marital disharmony in many homes. A broken home life can make children vulnerable to sexual abuse. Studies examining the prevalence of child sexual abuse in different types of families have also found that the overall number of children sexually abused by biological fathers to be greater because only a minority of children grow up with stepfathers. But indirect analysis of the studies found that proportionately more 'stepfathers' are abusing their divorced or never-married partner's children. ${ }^{23}$

\section{PREVENTING CHILD SEXUAL ABUSE: THE ISLAMIC PERSPECTIVES}

The solution to the problem that occurs to all mankind on this earth has already been provided by Islam that is mentioned in the Qur'an and Sunnah. The Shari'ah aims at safeguarding people's interest and preventing harm in this world and the hereafter. There are five basic

22 "A Comparison of Morality from the Religions from Around the World", available at http://usminc.org/other.html as cited by bismillahgroup at https://bismillahgroup.wordpress.com/2013/01/25/semua-agamamelarang-zina/ (accessed on 30 April 2021).

23 Patrick Parkinson, Child sexual abuse and the churches: understanding the issues (Sydney: Christian Medical Fellowship, Aquila Press, 2003) 19. 
necessities of human beings that must be protected by the Shari'ah which include the protection and promotion of religion, life, lineage, dignity, mind and property ${ }^{24}$. These are known as masalih (interests), which refers to human or public good, interest, welfare and utility. The protection of these interests is recognised by all jurists who also maintain that any transgression against these interests is considered unlawful and may be a punishable offence..$^{25}$

It is worth mentioning that the protection of these masalih (interests) is guaranteed to all human beings, including the victims and this has become the main concern of Shari'ah since the early days of Islam. There are many rulings of Shari'ah, which suggest measures to be taken in ensuring the safety of every member of community particularly that of the vulnerable person who is susceptible to a criminal act. These can be derived from the sources of Shari'ah, primarily the Qur'an and hadith of the Prophet S.A.W. Combating this catastrophe requires cooperation from all sectors whether individual, family, community and of course the state or authority. The next part of the article deals with the preventive measures to solve these problems that have been laid down by the Shari'ah.

\section{The role of an individual Muslim}

In order to prevent a child from being sexually abused, measures should be taken to block all channels leading to potential offenders from its root. It begins with an individual himself. Every Muslim must prepare himself or herself to be a good Muslim, doing whatever is made obligatory by the Shari'ah and abstain from doing whatever has been prohibited. Islam strongly emphasizes on the belief in Allah ('aqidah) and the feeling of God consciousness (taqwa). All Muslims accept the existence of Allah and life in the Hereafter. They are reminded that Allah is watching and every one of their actions is being recorded. This record will be placed before each and every individual on the Day of Judgement. Whether one is rewarded or punished will depend upon the nature of one's actions. Muslims accept that an act done in the thick

24 Imran Ahsan Khan Nyazee, Islamic Jurisprudence (Usul al-Fiqh), (Islamabad: The International Institute of Islamic Thought: Islamic Research Institute, 2000), 195-212.

25 Zaydan, Abd al-Karim, Majmu'at Buhuth Fiqhiyyah (Baghdad: Maktabat al-Quds, 1986) 384. 
layers of darkness may remain a secret in this world but cannot go unnoticed in the Hereafter. Even the feelings and passions that occur in the innermost recesses of the heart are known to Allah and cannot be overlooked. Hence, when a Muslim has such a strong belief, he surely would obey Allah's commands and abstain from His prohibitions. The Qur'an says:

Or do they think that We hear not their secrets and their private counsels? Indeed (We do), and our Messengers are by them, to record. ${ }^{26}$

The observation of 'ibadah plays an important role to restrict ways leading to the commission of crime. Daily prayers, for example, if performing the 'ibadah with khushu' (humility) can restrain Muslims from doing shameful deeds, ${ }^{27}$ as stated in the following Qur'anic verse:

And establish regular prayer: for prayer restrains from shameful and evil deeds. ${ }^{28}$

Similarly, fasting can be a shield (or protection) from the commission of crime, as mentioned in the following hadith:

Muaz ibn Jabal reported that the Prophet S.A.W. said, "Fasting is a shield", in other words, a shield against wrong action. ${ }^{29}$

As mentioned earlier, living in high-risk lifestyle increases the possibility of a person becoming an offender or victim. For instance,

26 Qur'an, 43:80. Abdullah Yusuf Ali, The Holy Qur'an: Arabic Text, with English Translation of the Meaning \& Selected Commentaries (Kuala Lumpur: Saba Islamic Media, 2009) 1066.

27 Abu Zahrah, Muhammad, al-'uqubah fi al-fiqh al-Islami (Cairo: Dar alFikr al-'Arabi, n.d.) p.24, For further details on the wisdom behind doing the prayer, see for example, al-Qaradawi, al- 'Ibadah fi al-Islam, 15th ed. (Cairo: Maktabah Wahbah, 1985), pp.225-242.

28 Qur'an, 29:45. Abdullah Yusuf Ali, The Holy Qur'an: Arabic Text, with English Translation of the Meaning \& Selected Commentaries (Kuala Lumpur: Saba Islamic Media, 2009) 827.

29 al-Nasa'i, Abu 'Abd al-Rahman b. Shu'ayb, Sunan al-Nasa'I ( Egypt: Matba'ah Mustafa al-Babi al-Halabi wa Awladuh. 1st ed. 1964) vol.iv, 163. 
consumption of intoxicants, taking drugs and involving in gambling would lead the perpetrator to commit further offence such as sexual abuse against children. The Qur'an states that:

$\mathrm{O}$ ye who believe! Intoxicants and gambling, sacrificing to stones, and (divination by) arrows are an abomination, of Satan's handwork: eschew such (abomination), that you may prosper. Satan's plan is (but) to excite enmity and hatred between you, with intoxicants and gambling. ${ }^{30}$

Drinking intoxicants is prohibited not only because it is a sin itself, but it is considered as a mother of evil which leads to other evil. The Muslims are also ordered to stay away from drinking parties or gatherings at which liquors are served. There is a hadith, which says:

Whoever believes in Allah and the Last Day must not sit at the table at which khamr (wine) is consumed. ${ }^{31}$

A person who is in the state of intoxication is incapable of distinguishing between right and wrong, good and evil. His actions may lead to acts, which disturb the peace and order of the family and may even lead to a father sexually abusing his own daughter. Drinking liquor is an evil and results in many harmful effects, the undesirable fact which is recognized by all rational and sensible persons the young and the old. It saps the very root of morality, self-control and Godconsciousness, making man an easy prey to evil. ${ }^{32}$

In the same vein, gambling is prohibited in Islam as it inculcates disputes among the gamblers, which finally assume the shape of enmity and hatred towards one another, although they may claim that losing does not trouble them. It also enslaves the gambler in the hands of

30 Qur'an, 5:90-91. Abdullah Yusuf Ali, The Holy Qur'an: Arabic Text, with English Translation of the Meaning \& Selected Commentaries (Kuala Lumpur: Saba Islamic Media, 2009) 213 -214.

31 al-Qaradawi, Yusuf, The lawful and the prohibited in Islam (Lahore: Islamic Publication (Pvt) Ltd, 1988) 74.

32 Siddiqi, Muhammad Iqbal, Why Islam forbids intoxicants and gambling (Lahore: Kazi Publications, 1981) 39. 
gambling and seldom succeeds in abandoning it. This can sometimes lead the gambler to prostitute his or her own child for money. ${ }^{33}$

\section{The responsibility of family}

The family laws of the Shari'ah are an embodiment largely of guidelines and measures to make the family a safe refuge for all of its members. ${ }^{34}$ It is promoted through the maintenance of healthy family life, the institution of marriage, individual rights to privacy, not exposing or accusing others of misbehavior and ensuring that the relationships between men and women are done in respectful and responsible way. The institution of marriage has been made as easy as possible and a great stress has been laid upon living in a married state, as confirmed by the following Qur'anic verse and hadith which say:

Marry those among you who are single, or the virtuous ones among your slaves, male or female..$^{35}$

O assembly of young people! Whoever of you has the means to support a wife, he should get married, for this is the best means of keeping the looks cast down and guarding chastity. ${ }^{36}$

When a servant of Allah marries, he perfects half of his religion. ${ }^{37}$

The above texts indicate the importance of marriage in overcoming the traps of evil. When a person gets married, his life is settled. This call to marriage also aims at satiating the yearning for sexual pleasure, which

33 Ibid. 144.

34 Qur'an, 4:3. Abdullah Yusuf Ali, The Holy Qur'an: Arabic Text, with English Translation of the Meaning \& Selected Commentaries (Kuala Lumpur: Saba Islamic Media, 2009) 138.

35 Qur'an, 24:32. Ibid. 712.

36 Muslim, Abu al-Husayn Muslim ibn al-Hujjaj, Mukhtasar sahih Muslim. 6th ed. (Beirut: al-Maktab al-Islami, 1987) 207.

37 Fazlul Karim, Mishkat ul-masabih: An English translation and commentary (New Delhi: Islamic Book Service, 1988), vol.ii, 619. 
if uncontrolled by marriage, may lead to crimes such as rape and other sexual offences including that against children. ${ }^{38}$

In Islam, as servants of Allah, husbands and wives have distinct roles to play in ensuring the smooth running of their family lives. A man is responsible to give maintenance and protection to his family. To shoulder this responsibility, a man is regarded as a leader of his family with certain leadership attributes. ${ }^{39}$ Thus, a husband is in charge of preparing a pure family environment and educating his family particularly with fardu 'ain (the knowledge on imperative duties). He is also responsible to ensure that every member of his family observes his or her religious duties as well as prevent them from indulging in unlawful act, as urged in the following Qur'anic verse and hadith which say:

O ye who believe! Save yourselves and your families from a Fire whose fuel is men and stones. ${ }^{40}$

The Prophet S.A.W. said: Beware, every one of you is a shepherd and everyone is answerable regarding his flock. The imam is a shepherd over his subjects and a man is a guardian over the members of his family and shall be questioned about them. ${ }^{41}$

As a leader of the family, a father or guardian must protect his family members particularly the young ones from any menace that may harm them. In doing so, he should teach and guide their children with proper knowledge so that they are fully aware of the threats of transgression including that of sexual abuse.

For the sexual training of children, the parents must guide their children not to enter parents' bedroom without asking permission. This is highlighted in the Qur'an, which states:

38 Siddiqi, The Penal Law of Islam (Lahore: Kazi Publication, 1985) 15.

39 See: Qur'an, 4:34.

40 Qur'an, 66:6. Abdullah Yusuf Ali, The Holy Qur'an: Arabic Text, with English Translation of the Meaning \& Selected Commentaries (Kuala Lumpur: Saba Islamic Media, 2009) 1271.

41 Al-Bukhari, Kitab al-Nikah, Bab al-Mar'ah ra'iyah fi Bait Zaujiha, Hadith no. 5188. 
O ye who believe! Let those whom your right hands possess and the (children) among you who have not come of age ask your permission (before they come to your presence) on three occasions: before morning prayer; the while you doff your clothes for the noonday heat; and after the late-night prayer: these are your three times of undress: outside those times it is not wrong for you or for them to move about attending to each other: thus, does God make clear the Signs to you: for God is full of Knowledge and Wisdom. But when the children among you come of age, let them (also) ask for permission as do those before them. Thus, does God make clear His Signs to you: for God is full of Knowledge and Wisdom. ${ }^{42}$

The above verse mentions that once children have reached the age of which they are able to ask permission, they should no longer spend the night in the parents' room. In doing this, a husband is required to provide a decent home for his family that can accommodate separate rooms for daughter and son as advised by the hadith of the Prophet S.A.W. which says:

Order your children to observe prayer when they reach the age of seven and beat them (lightly) for not observing it when they reach the age of ten and arrange their beds (for sleeping) separately. ${ }^{43}$

It is worth to mention that one of precautionary measures taken in Shari'ah to prevent incest from occurring in the family is by requiring each of its member to observe his or her 'awrah. Even though the Muslim scholars agree that a woman does not have to observe strict rules of covering the 'awrah in front of her mahrams ${ }^{44}$ there is still certain rules that need to be observed. A woman is only allowed to

42 Qur'an, 24:58-59. Abdullah Yusuf Ali, The Holy Qur'an: Arabic Text, with English Translation of the Meaning \& Selected Commentaries (Kuala Lumpur: Saba Islamic Media, 2009) 719-720.

43 Abu Dawud, Sulayman b. al-Ash'ath al-Sijistani al-Azdi, Sunan Abi Dawud (Beirut: Dar Ibn Hazm, 1988), Hadith No: 495.

44 Mahram means a person who is in a degree of consanguinity, affinity or fosterage precluding marriage such as the father, brother, son, paternal uncle (father's brother), maternal uncle (mother's brother), father in-law, grandson, husband's son (from another marriage), son in-law, etc. 
expose parts, which usually appear such as hair, face, arms, hands, legs from below the knees, and feet. It will not be permissible to expose the stomach, back or any area which is between the navel and knees. Besides, a Muslim woman must always remember that she is known for her modesty (haya), therefore she must never make a wanton display of herself. This ruling is based on the verse of the Qur'an, which says:

And say to the believing women that... they should not display their beauty except to their husbands, their fathers, their husbands' fathers, their sons, their husbands' sons, their brothers or their brothers' sons, or their sisters' sons, or their women... ${ }^{45}$

Shari'ah also concerns about the safety of every member of the community particularly those who are vulnerable. Measures have been taken to prevent the children, the mentally retarded person, women, the elderly and those who are weak in general from criminal victimization through the concept of guardianship (waliy). In the case of children or young persons including the orphans and the mentally retarded persons, the guardian is responsible for the care of their person and property. ${ }^{46}$ The guardian must provide them with basic necessities such as food, shelter and education so that they are safe and protected from being victimized due to their incapacity.

When a girl (or a child) has neither a father nor grandfather nor any of her 'asabah (remote/distant kindred) to take charge of her, or if the 'asabah is immoral, it is a duty of the authority to take care of her condition. If she can be trusted to take care of herself, she should be allowed to live alone; otherwise, she should be placed with some

45 Qur'an, 24: 31. Abdullah Yusuf Ali, The Holy Qur'an: Arabic Text, with English Translation of the Meaning \& Selected Commentaries (Kuala Lumpur: Saba Islamic Media, 2009) 711-712.

46 The guardianship of a minor for the management and preservation of his property devolves (1) first on his or her father, (2) then on the father's executor, (3) next on the paternal grandfather, (4) then on his executor, (5) then on the executors of such executors, (6) finally on the ruling power or his representative i.e. a judge. Ultimately it rests upon the judge to appoint a guardian for an infant's property when there is no near guardian (i.e., the father, the father's father and their executors). 
female trustee. ${ }^{47}$ Besides, the women or children are not allowed to travel alone unless accompanied by their guardian or mahram who can ensure their safety during the travel. This ruling is essential to protect those who are lesser in physical strength from becoming the victim of rape, sexual assault or robbery. There is a hadith of the Prophet S.A.W., which says:

A woman should not travel alone except with a mahram. And a man should not be alone with a woman unless her mahram with her. Suddenly a man asked: O Messenger of Allah! I will go out to war, and my wife is going for hajj (pilgrimage). Then the Prophet S.A.W. said: Then accompany your wife to perform hajj. $^{48}$

This ruling is meant as precautionary measure aimed at ensuring that women and children are protected, at all times and do not allow themselves to be victimized easily.

\section{The responsibility of community}

The Muslim community plays a very important role to ensure its members live in peace and harmony by enforcing several measures, such as the institution of zakat. Zakat (obligatory alms) is the allocation of wealth, which is taken compulsorily from the rich and distributed amongst the poor. Paying zakat may promote Muslims to help their less fortunate brothers. This obligation will help to close the gap between them. Payment of zakat also helps those needy persons in alleviating their burden by fulfilling their basic needs such as food, clothing and shelter so that they will be less dependent on others for survival and this is particularly so for women and children. Thus, the

47 Zaydan, Abd al-Karim, Al-Mufassol fi ahkam al-mar'ah wa bait alMuslim fi al-Shariah al-Islamiyyah, 3rd ed. (Beirut: Muassasah alRisalah, 2000) 347.

48 Muslim, Abu al-Husayn Muslim ibn al-Hujjaj, Mukhtasar sahih Muslim, 6th ed. (Beirut: al-Maktab al-Islami, 1987) 172. 
bad consequences, which result from poverty including child sexual abuse, could be avoided. ${ }^{49}$

The neighbourhood also has a significant part in preventing child sexual abuse in the respective area. Duties towards neighbours are emphasized in Islam. A person must be caring and kind to his neighbour. Every sort of help should be extended towards neighbour without any discrimination of caste, race or religion. Each member of the community should be alert and proactive about his or her neighbours' problems or even offences which are suspected to be committed by their neighbours particularly those related to domestic violence and child sexual abuse so that the place of residents is always in peace and harmony. The Prophet S.A.W. said:

Do you know what the duties of a neighbour are? Help him if he seeks your help, give him loan if he is in urgency, give him relief if he is needy, nurse him if he falls ill, follows his bier if he dies, cheer him if he meets any good, sympathize with him if any calamity befalls him... 50

Thus, each member of the community is advised to become a responsible neighbour to ensure that criminal victimization in the area is prevented. Neighbours should act as guardian towards each other especially in watching their neighbourhood area.

Another most important measure in preventing criminal victimization is the concept of proper guardian for the whole society known as hisbah. The hisbah promotes the campaign of amr ma'ruf and nahy munkar (to enjoin good and forbid evil) in the society through the officer in charge known as muhtasib who is appointed by the

49 Poverty has been identified as one of the risk factors of violence against children including sexual abuse as confirmed by WHO (https://www.who.int/news-room/fact-sheets/detail/violence-againstchildren) accessed on 5 November 2020. For further details on the roles of zakat, see for example, al-Qaradawi, al-'Ibadah fi al-Islam, 15th ed. (Cairo: Maktabah Wahbah, 1985) 255-294.

50 Fazlul Karim, Mishkat ul-masabih (New Delhi: Islamic Book Service, 1988) 253. 
authority concerned..$^{51}$ The concept of hisbah is based on the Qur'anic verse, which says:

Let there arise out of you a band of people inviting to all that is good, enjoining what is right and forbidding what is wrong. ${ }^{52}$

The presence of a muhtasib would ensure the prevention of criminal victimization and thus community in general will live in peace and harmony. In the Malaysian context, the concept of hisbah has been implemented even though the term hisbah is not explicitly used. The Royal Malaysian Police, for example, is responsible for enforcing the law and maintaining peace and order of the society. At the state level, Religious Department of each state has established an enforcement division through which Religious Enforcement Officer is appointed to carry out the duty similar to that of a muhtasib. The concept of hisbah can also be extended to other body or committee in the community to monitor the activities of its members in matters relating to morals, religion and economy with the aim of maintaining peace, justice and dignity as laid down by Shari'ah. Besides, it is also a duty of every member of the community to encourage one another to acts of piety and the restraint of evil. These controls help closing all the channels, which lead to the commission of evil including sexual abuse against children. ${ }^{53}$

\section{The responsibility of the Authority}

Attempts have been taken in Islam to eradicate all the causes, which lead to the commission of crimes, which directly or indirectly curb the cases of child sexual abuse. First of all, the authority of a Muslim state is responsible for the support of every citizen, regardless of his caste, race, language, colour or social status. It should try as far as possible

51 See: Ibn Taymiyyah, Ahmad ibn Abd a-Halim, al-Hisbah fi al-Islam (Beirut: Dar al-Kutub al-'Ilmiyyah, 1992) and al-Nabahan, Muhammad Faruq, Nizam al-hukm fi al-Islam (Morocco: Muassasah al-Risalah, 1983) 618.

52 Qur'an, 3:104. Abdullah Yusuf Ali, The Holy Qur'an: Arabic Text, with English Translation of the Meaning \& Selected Commentaries (Kuala Lumpur: Saba Islamic Media, 2009) 112.

53 See: Abu Zahrah, Muhammad, al-'uqubah fi al-fiqh al-Islami (Cairo: Dar al-Fikr al-'Arabi, n.d.) 25. 
to ensure that the citizen get their basic needs (dharuriyyat) such as food, clothing, shelter, medical treatment, and education. The authority should also make an attempt to provide sufficient jobs for all citizens. Where a job is not available or if an individual is incapable of working, aid should be given to him from the bayt al-mal (public treasury). ${ }^{54}$ Regarding this matter, Muhammad Asad, as quoted by M.Siddiqi, explains:

In a community or state which neglects or is unable to provide complete social security for all its members, the temptation to enrich oneself by illegal means often becomes irresistible ... If the society is unable to fulfil its duties with regard to every one of its members, it has no right to invoke the full sanction of Criminal Law (hadd) against the individual transgressor, but must confine itself to milder forms of administrative punishment... ${ }^{55}$

The last measure taken to combat child sexual abuse from Islamic perspective is through a warning of the infliction of punishments. If one still turns to crime despite the above-mentioned safeguards, then he deserves to be punished. It should be remembered that before the infliction of any punishment, certain conditions and procedures should be followed by the court. Punishment for committing the offence of sexual abuse against children must be severe. In Islamic criminal law, illicit sexual intercourse out of wedlock, which is committed with consent of both adult man and woman or known as zina, is considered an offence that is liable to severe hadd punishment. Thus, it should be considered more serious when the offence is committed without consent of the other party or the consent is given by a person who is incapable of giving legal consent such as a child. This is-known as rape which also covers other acts of sexual abuse such as incest or sodomy.

Rape cannot be categorized as zina since the nature of both offences is different. Some scholars categorize rape as hirabah. Sayyid Sabiq defines hirabah as "an act of causing fear or unrest to the community by killing people, robbing their properties, assaulting or

54 al-Dhahabi, Muhammad Husayn, Athar iqamat al-hudud fi istiqrar almujtama' (Matba'ah Wahbah, 1965) 12.

55 Siddiqi, Muhammad Iqbal, The penal law of Islam, $2^{\text {nd }}$ ed. (Lahore: Kazi Publications, 1985) 136. 
raping women, destroying livestock and plants". ${ }^{56}$ Meanwhile, Ibn Hazm defines muharib (the person who commits hirabah) as a person who causes fear to people on the highway whether he is equipped with weapon or not, whether it is committed at daytime or nighttime, whether it is committed inside populated area or outside populated area, whether it is committed by one offender or group of offenders that causes the victim to be afraid of being killed, robbed, or raped. ${ }^{57}$ The punishment of hirabah is mentioned in the Qur'anic verse, which says:

The punishment of those who wage war against God and His Messenger, and strive with might and main through the land is: execution, or crucifixion, or the cutting off of hands and feet from opposite sides, or exile from the land: that is their disgrace in this world; and a heavy punishment is theirs in the hereafter. ${ }^{58}$

Based on the previous discussion, it can be said that the offence of sexual abuse against children is considered as rape and thus the offender can be liable to hadd al-hirabah under Islamic law.

Beside the above views, rape can also be categorized as ta'zir offence since the offence of rape and its punishment are not mentioned clearly in the text of the Qur'an and hadith. It is therefore, left to the discretion of the ruler or judge to determine the most suitable punishment on rapist. It should be noted that $t a$ 'zir punishment does not mean a less severe punishment. It can be as severe as death sentence depending upon the discretion of a judge. ${ }^{59}$ In addition to punitive measures, the rapist should also be required to pay compensation to the victim under the law of qisas and diyat since the offender has caused bodily harm and injury (al-jurh) to the victim. ${ }^{60}$ As far as Islamic law is concerned, the blood, body, dignity and property of a Muslim are

56 Sayyid Sabiq, Fiqh al-sunnah, $10^{\text {th }}$ Edition (Makkah, 1993), vol. 2, 450.

57 Ibid.

58 Qur'an, 5:33. Abdullah Yusuf Ali, The Holy Qur'an: Arabic Text, with English Translation of the Meaning \& Selected Commentaries (Kuala Lumpur: Saba Islamic Media, 2009) 197-198.

59 El-Awa, M. Salim, Punishment in Islamic law: A comparative study (Indianapolis: American Trust Publications, 1982) 106-109.

60 Malik ibn Anas, Muwatta (Granada: Madinah Press, 1989) 303; Ibn Qudamah, Muhammad al-Maqdisi, Al-Mughni 'ala mukhtasar al-kharaqi (Cairo: Dar al-Kutub al-'Ilmiyyah, 1994), Vol. 8, 3. 
sacred and inviolable, the violation of which amounts to a serious breach of law.

\section{CONCLUSIONS AND POLICY RECOMMENDATIONS}

Sexual abuses against children are serious issues that must not be neglected as this will affect future generations that are supposed to lead the country. A child is vulnerable to become an easy target to be abused because of their physical and mental conditions are infirm and fragile.

In order to ensure a safe community, concentration cannot only be given to the physical environment but attention must also be given to the development of the spiritual aspects of a person. Islam has long been concerned about this issue and provides measures to prevent a child from becoming a victim of sexual abuse. There are many rulings of Shari'ah which suggest measures to be taken in ensuring the safety of every member of community particularly that of the vulnerable person who is susceptible to a criminal act. These can be derived from the sources of Shari'ah, primarily the Qur'an and hadith of the Prophet S.A.W. combating this issue requires the cooperation from all sectors whether individual, family, community and of course the state or authority.

Prevention of sexual abuse against children can be a reality if the government ensures that the community is empowered with substantial knowledge of the Shari'ah and the conscious practice of Muslims as a whole. The government could also play an active role in adopting these principles as a matter of policy. 